\title{
Banking Sector Liquidity and Financial Crisis in Nigeria
}

\author{
Samuel O. Fadare \\ Research Candidate in Economics, Faculty of Business and law \\ Leeds Metropolitan University \\ Tel: 44-798-560-6779 E-mail: olutadef@yahoo.co.uk
}

Received: April 18, 2011

Accepted: April 28, 2011

doi:10.5539/ijef.v3n5p3

\begin{abstract}
Employing a linear least square model and time series data from 1980 to 2009, this paper studies the determinants of Banking Sector liquidity in Nigeria and assesses the extent to which the recent financial crises affected liquidity in deposit money banks in the country. The paper makes some interesting findings. First, we find that only liquidity ratio, monetary policy rate and lagged loan-to-deposit ratio are significant for predicting Banking Sector liquidity. Secondly, we find that a decrease in monetary policy rates, liquidity ratios, volatility of output in relation to trend output, and the demand for cash, leads to an increase in current loan-to-deposit ratios; while a decrease in currency in circulation in proportion to Banking Sector deposits; and lagged loan-to-deposit ratios leads to a decline in current loan-to-deposit ratios.
\end{abstract}

Our result suggests that during periods of economic or financial crises, deposit money banks are significantly illiquid relative to benchmarks, and getting liquidity monetary policies right during these periods is crucial in ensuring the survival of the Banking Sector.

Keywords: Banking Sector, Deposit Money Banks, Central Bank of Nigeria, Liquidity

JEL classification: E52, E58, G21, G28

\section{Introduction}

A key activity of the Central Bank of Nigeria (CBN) is liquidity management. According to the CBN Act of 1958 and its subsequent amendments, the $\mathrm{CBN}$ is responsible for implementing restrictive or expansionary monetary policies in order to achieve price stability, influence interest rates, manage the growth in credit to the domestic economy and maintain the international value of the local currency. It manages Banking Sector liquidity by supplying or withdrawing liquidity from the Banking Sector which it deems to be consistent with a desired level of short-term interest rates or reserve money. It relies on the daily assessment of the liquidity conditions in the banking system, so as to determine its liquidity needs and thus, the volume of liquidity to inject or withdraw from the economy. (See Ibeabuchi 2007).

To this end, the Banking Sector plays an important role in the Nigerian economy. According to Soludo (2009:23), Nigerian banks account for over 90 percent of financial system assets and dominate the stock market. As a result, a well funded Banking Sector is essential in order to maintain financial system stability and confidence in the economy.

A significant body of literature exists on the determinants of banking liquidity; some of these include studies by Agénor et al (2004), Aspachs et al (2005), and Winston (2009). Previous studies reflect efforts to explain the variation in Banking Sector liquidity over different periods. The relationship between Banking Sector liquidity and Banking Sector prudential regulations in Nigeria, however, has largely been ignored. The only relevant study identified is that by Uremadu (2009) which uses several money market variables in modelling a liquidity demand function for the Nigerian economy. The estimated model is however not very robust as it explains less than 30 percent of the variation in Banking Sector liquidity over a 25 -year period. In addition, it appears that only one of the explanatory variables has a significant effect on the dependent variable while the estimation period falls short of the banking crisis that began in 2007, as such, it does not assess the impact of financial crisis on Banking Sector liquidity. Further, Uremadu (2009) specified a demand function for Banking Sector liquidity using Banking Sector liquid assets as a proportion of deposit liabilities held within the sector, however, given that bank loans are the largest components of deposit money banks' asset portfolios and are funded by a combination of shareholders' funds and deposit liabilities, the total loan-to-total deposit ratio is a better measure of Banking Sector liquidity compared to the current assets to deposit liability ratio.

The recent global financial crisis and its impact on the Nigerian Banking Sector has shown that CBN's daily forecasts of Banking Sector liquidity is not sufficient in assessing the liquidity requirements of the sector as several 
banks remain relatively fragile and incapable of withstanding periodic liquidity shocks. According to Alford (2010: 6) "Following the special examination and during the period from December 2008 to December 2009, Nigerian banks wrote off loans equivalent to $66 \%$ of their total capital; most of these write offs occurred in the eight banks receiving loans from the CBN". Most of the banks also suffered panic runs and flights to safety during the period.

This study will therefore attempt to rectify the gap in economic literature by 1) tracing the development of Nigerian banking liquidity regulations and its impact on the economy 2) identifying the key determinants of banking liquidity in Nigeria, and 3) assessing the relationship between determinants of Banking liquidity and financial frictions within the economy.

The remainder of the paper is organised as follows. Section 2 undertakes an overview of Nigerian Banking liquidity regulations up to the end of 2009. Section 3 contains a review of some related theoretical and empirical literature. Section 4 deals with a description of data sources, model specification, methodology and hypotheses. Section 5 covers the analyses of available data, extension of the specified model into dynamic forecasts and interpretation of the results. Section 6 provides a synopsis of the study, policy recommendations and outlines possible areas of future research.

\section{Trends in Nigerian Banking Sector Liquidity Regulation}

Banking was introduced into Nigeria in 1892 with the establishment of the African Banking Corporation which was subsequently acquired by the Bank of British West Africa in 1894; however, the banking system remained rudimentary with economic activities carried out either by barter or use of commodity money. (Note 1). According to Adekanye (1986:21) "There was no monetary system in Nigeria before 1912 when the West African Currency Board (WACB) was established". He added that "The West African Currency Board introduced the West African Pound to replace the variety of circulating media of exchange in these territories." WACB was however only established to issue West African Pounds and to ensure convertibility of the West African Pounds into English Pounds. It therefore could not control the demand for or supply of money. In 1917, Barclays Bank DCO was established. These two banks had a virtual monopoly on banking business up until the end of the Second World War. (Note 2).

After the end of the Second World War, there was an indigenous banking boom with 185 so called 'mushroom banks' registered between 1947 and 1952, although most did not actually commence operations. Most of the banks that did start operating collapsed within a few years due to a combination of mismanagement, insider lending and inadequate capitalisation. Only four of the banks set up by local investors during the colonial period survived until independence in 1960, all with the aid of substantial financial support from the regional governments, whose explicit policy was to support the efforts of indigenous banks to finance local businesses. These banks were also used to finance political activity and to channel loans to party supporters as well as the banks' directors. The introduction of the 1952 Banking Ordinance which for the first time in Nigeria imposed entry conditions for banks such as minimum capital requirements, and the loss of public confidence induced by the failure of local banks, brought the indigenous banking boom to an end by the mid 1950s (Nwankwo 1980: 45-53). For the first time, indigenous banks were required to have a minimum paid-up capital of $£ 12,500$ while foreign banks were required to have a minimum paid-up capital of $£ 100,000$. Banks were also required to maintain a reserve into which a minimum of 20 percent of their annual profits had to be paid. The 1952 Banking Ordinance was however ineffective in managing banking liquidity. (Note 3)

Ajayi and Ojo (1981:23) identified several defects of the 1952 Banking Ordinance. It did not make any provision for assisting banks in need as there was no Central Bank to act as 'lender of last resort'; banks kept cash idle as there were limited investment avenues and also to maintain the required level of liquidity. The Banking Ordinance of 1958 was subsequently enacted, establishing the Central Bank of Nigeria. The 1958 Banking Ordinance raised the minimum statutory reserve from 20 percent to 25 percent of annual profits; maximum lending to any one borrower was limited to 20 percent of the sum of paid-up capital and statutory reserves; and specified a list of acceptable liquid assets. The 1958 Banking Ordinance was amended in 1962; the amendment raised the minimum paid-up capital of indigenous banks from $£ 12,500$ to $£ 250,000$ while foreign banks were required to maintain a minimum of $£ 250,000$ worth of assets in Nigeria.

The 1958 Banking Ordinance and its 1962 amendment were repealed in 1969 and replaced by the Banking Act of 1969. The Banking Act of 1969 empowered the CBN to stipulate minimum holding by banks of cash reserves, specified liquid assets, special deposits and stabilization securities. The maximum lending to a single borrower was also increased from 20 percent to 33.3 percent of the sum of paid-up capital and statutory reserves. An IMF-supported Structural Adjustment Programme (SAP) was introduced in 1986 in order to encourage competition and market-led resource allocation. NCEMA (2003:7) explained that SAP "emphasized reliance on market forces 
and the private sector in dealing with the fundamental problems of the economy." The package of financial reforms introduced during this period led directly to an increase in deposit money banks from 40, pre-1986, to 120 in 1992. In 1990, entry into the Nigerian Banking Sector was further liberalized as foreign banks were allowed to open offices in the country. CBN Decree 24 and the Banks and Other Financial Institutions Decree 25 both of 1991, which repealed the Banking Decree 1969 and all its amendments, were, thereafter, enacted to strengthen and extend the powers of CBN to cover new institutions in order to enhance the effectiveness of monetary policy, regulation and supervision of banks as well as non-banking financial institutions. By 1998, however, the number of deposit money banks in operation had whittled down to 89 with the monetary authorities liquidating 30 terminally distressed deposit money banks.

By end of March 2004, although there were still 89 deposit money banks in Nigeria, 14 were assessed as being only marginally sound, 11 unsound and 2 not rendering any returns to the monetary authorities during the period. According to Soludo (2004:3), the problems with the unsound deposit money banks included persistent illiquidity, poor asset quality, weak corporate governance and gross insider abuses. The minimum capital requirement at the time was US\$7.53 million for existing banks and US\$15.06 million for new banks with most Nigerian banks having a capitalization of less than US\$10 million. The weak capital base of some of the ailing banks was evidenced by their overdrawn accounts with the Central Bank of Nigeria and high incidence of non-performing loans.

Okonjo-Iweala and Osafo-Kwaako (2007:15) explained that "To strengthen the financial sector and improve availability of domestic credit to the private sector, a bank consolidation exercise was launched in mid-2004. The Central Bank of Nigeria requested all deposit banks to raise their minimum capital base from about US\$15 million to US $\$ 192$ million by the end of $2005 \ldots$ in the process of meeting the new capital requirements, banks raised the equivalent of about $\$ 3$ billion from domestic capital markets and attracted about $\$ 652$ million of FDI into the Nigerian banking sector."

Although sufficiently capitalized, the financial crisis which began late in 2007 showed that Nigerian depost money banks were not resilient enough to withstand liquidity shocks and continued to rely on significant liquidity support from the monetary authorities. According to Fadare (2011:203), "Between August and December 2009 for example, the Central Bank of Nigeria injected the equivalent of US\$4.1 billion into 10 Nigerian banks adjudged to be facing grave liquidity crisis, sacked 8 bank CEOs, introduced a plethora of regulations and took other direct actions deemed necessary in order to safeguard the Banking Sector from systemic collapse and to ensure the stability and soundness of Nigeria's banking sector."

By the end of the third quarter of 2009, broad money (M2) showed an increase of 5.6 per cent on a year-on-year basis. The trend in money supply movement was a reflection of the fall in net foreign assets and slowdown in credit to the private sector. The gross official foreign reserves had fallen from US\$54.22 billion at the end of January 2008 to US\$43.34 billion as at end September 2009. To improve liquidity and financial stability in the Nigerian banking system, the Monetary Policy Committee of the CBN in November 2009 introduced several policy measures including quantitative easing to bridge the gap estimated at approximately N500 billion (US\$3.3 billion) between the levels of current monetary aggregates and the benchmark levels for 2009; redemption of promissory notes issued by the monetary authorities; and the lifting of the ban on the use of Bankers' Acceptances and Commercial Papers. Despite the various policy measures implemented by the CBN to improve Banking Sector liquidity, key economic variables deteriorated. For example, the headline inflation rate was 12.4 percent in November 2009, up from 11.6 and 10.4 percent recorded in October and September, 2009 respectively. Reserve money was also below the indicative benchmarks for most of 2009 while the annualized growth rate of private sector credit was 26.10 percent, significantly below the indicative benchmark of 45 percent. The average maximum lending rate rose to 23.1 percent in November 2009 from 22.97 percent in September 2009 while the average prime lending rate rose to 18.93 percent in November 2009 from 18.33 percent in September 2009, In November 2009, the Wholesale Dutch Auction average exchange rate stood at N150.85 per US dollar compared with N149.3578 per US dollar in October 2009, representing a depreciation of 1.0 percent. (Note 4 ).

\section{Earlier Literature}

\subsection{Empirical Studies}

Agénor et al (2004) analyze factors underlying the fall in credit in East Asia by specifying a model of excess liquidity reserves. They defined excess liquidity ' $Z$ ' as the difference between total reserves ' $R$ ' and the product of the reserve rate and total deposit liability. They calculated the volatilities of currency to deposit ratio and manufacturing output to trend component ratio, as the standard deviation of the specified variable divided by the average of it for three leads and lags, centered on the current period. According to Agénor et al (2004), an excess liquidity demand function where banks' holding of excess liquidity over and above liquidity requirements was a 
function of the excess reserves to deposits lagged by one year; the rate of required reserves to deposits, the volatility of the ratio of cash to deposits; the volatility of the ratio of output to trend output, the ratio of output to trend output; and the penalty rate proxied by either the discount rate or the money market rate.

Using patterns of excess liquidity in sub-Saharan Africa, Saxegaard (2006) extended Agénor et al's (2004) model by proposing a framework for how a decomposition of excess liquidity can be achieved. Saxegaard (2006) adjusted Agénor et al's (2004) model by using the five-year moving averages of the standard deviation of the output gap and the cash to deposit ratio, respectively. Additional explanatory variables were also added to Agénor et al (2004) model, including ratio of demand to savings deposits; private sector and government deposits, expressed as a fraction of GDP; the ratio of private sector credit to GDP; the ratio of bank credit to the central government and public enterprises to GDP; the ratio of securitized domestic debt to GDP; the ratios of aid inflows and oil exports to GDP; the quarterly percentage change in the oil-price.

Aspachs et al (2004) use both micro (likelihood of obtaining lender of last resort support in case of a liquidity shortage; interest margin; profit; loan growth; Tobin's Q; and size) and macro (GDP growth and short-term interest rates) explanatory variables to analyze the determinants of UK banks' liquidity policy and investigate how the Bank of England lender of last resort policy affects banks' liquidity buffers.

\subsection{Theoretical Background}

Moore (2009:9) explained that "a bank needs to hold liquid assets to meet the cash requirements of its customers ... if the institution does not have the resources to satisfy its customers' demand, then it either has to borrow on the inter-bank market or the central bank". It follows therefore that a bank unable to meet its customers' demands leaves itself exposed to a run and more importantly, a systemic lack of confidence in the banking system. Bordo et al (2001), suggest two explanations on the cause of liquidity runs on deposit money banks. They explained that runs on banks are a function of mob psychology or panic, such that if there is an expectation of financial crisis and people take panic actions in anticipation of the crisis, the financial crisis becomes inevitable. Bordo et al (2001:58) also "asserts that crises are an intrinsic part of the business cycle and result from shocks to economic fundamentals. When the economy goes into a recession or depression, asset returns are expected to fall. Borrowers will have difficulty repaying loans and depositors, anticipating an increase in defaults or non-performing loans, will try to protect their wealth by withdrawing bank deposits. Banks are caught between the illiquidity of their assets (loans) and the liquidity of their liabilities (deposits) and may become insolvent."

Using a single bank, Diamond and Dybvig (1983), developed a model which showed that bank deposit contracts can provide allocations superior to those of interbank markets, offering an explanation of how banks subject to runs can attract deposits. Brighi (2002) however show that abandoning the hypothesis of a single bank increases the relevance of the interbank market. Further, the probability of a banking crisis at a single bank decreases when interbank transactions are introduced - relative to a stand-alone bank. Indeed, Diamond and Dybvig (1983:416) acknowledge that "if many banks were introduced into the model, then there would be a role for liquidity risk-sharing among banks".

According to Brighi (2002), in a theoretical framework where liquidity crises are not only caused by bank runs, and where there is uncertainty about the proportion of depositors who may want to withdraw deposits, doing away with the assumption of an autarchic banking system decreases the risk of bank failure as a single bank on its own would be unable to meet depositors' demands.

To manage their liquidity risk and take decisions on how much cash and other liquid assets they should hold, Agénor et al (2004:30) hypothesize that "banks internalize the fact that they can draw funds from either the interbank market or the central bank in case of unexpected contingencies." They added that in the event of illiquidity, banks must borrow the missing reserves at a penalty rate; this is the opportunity cost of not holding sufficient reserves.

\section{Data}

\subsection{Hypotheses}

Hypothesis 1: A decrease in the monetary policy rate leads to a rise in the loan to deposit ratio as demand for loans are expected to rise as borrowing cost falls.

Hypothesis 2: A decrease in the liquid assets ratio results in a rise in the loan to deposit ratio as deposit money banks divert their liquid assets into more profitable liabilities.

Hypothesis 3: An increase in output volatility and positive changes in the demand for cash causes deposit money banks to call in loans as they accumulate cash in readiness for uncertain customer demand for cash withdrawals. This also implies that increases in output volatilities, positive changes in demand for cash and liquidity ratios leads 
to a decline in loan-to-deposit ratios.

\subsection{Model Specification}

Based on theoretical considerations, the estimated liquidity demand model is given by the following autoregressive linear least squares specification.

$$
\ln (L D)_{t}=a_{1} \ln (L D)_{t-1}+a_{2} \ln (L Q)_{t}+a_{3} C V[\ln (C / D)]_{t}+a_{4} C V\left[\ln \left(Y / Y^{T}\right)\right]_{t}+a_{5}\left[\ln \left(Y / Y^{T}\right)\right]_{t}+a_{6} r+\varepsilon
$$

Where $\varepsilon$ is the stochastic error term which is introduced into the model to capture all other variations in the dependent variable not captured by the explanatory variables. In $(\boldsymbol{L D})_{t}$ the dependent variable, is the natural $\log$ of the ratio of total loan to total Banking Sector deposits; $\ln (\boldsymbol{L D})_{t-1}$ is the natural $\log$ of the ratio of total loan to total Banking Sector deposits lagged one year; $\ln (\boldsymbol{L} \boldsymbol{Q})_{t}$ is the natural $\log$ of the ratio of total specified liquid assets to total current liabilities; $C V$ In $(\boldsymbol{C} / \boldsymbol{D})]_{t}$ is the volatility of the natural $\log$ of the ratio of currency in circulation to total Banking Sector deposits; $\boldsymbol{C} \boldsymbol{V}\left[\boldsymbol{l n}\left(\boldsymbol{Y} / \mathbf{Y}^{\boldsymbol{T}}\right)\right]_{t}$ is the volatility of the natural $\log$ of output to trend output; $\boldsymbol{l n}\left(\boldsymbol{Y} / \mathbf{Y}^{\boldsymbol{T}}\right)_{t}$ is proxy for changes in the demand for cash for manufacturing and transactional purposes and ' $r$ ' is the monetary policy rate which acts as the nominal anchor for other rates and also determines the lower and upper band of the CBN standing facility. The coefficient of variation for the log of currency to deposit ratio, $C V[\ln (\mathrm{C} / \mathrm{D})]$, is equal to the standard deviation of the specified variable divided by the average of it for 3 leads and lags, centred on the current period. The log of manufacturing output to trend component ratio, $\mathrm{CV}\left[\ln \left(\mathrm{Y} / \mathrm{Y}^{\mathrm{T}}\right)\right]$ is equal to the standard deviation of the specified variable divided by the average of it for 3 leads and lags, centred on the current period. Currency, $\mathrm{C}$, is defined as currency in circulation outside of deposit money banks. The Currency outside Banks is equal to Currency in Circulation less Cash held in Bank Vaults. Total deposits are the sum of demand, time, and savings deposits in deposit money banks. Manufacturing output, Y, is a seasonally-adjusted index, with 1990 as a base period. The trend component of manufacturing output, $\mathrm{Y}^{\mathrm{T}}$, is the quadratic trend which is equal to the fitted value obtained by regressing $\mathrm{Y}$ on constant term, time and time squared variables.

Data for Loan-to-Deposit ratio, Liquidity Ratio, Currency in Circulation outside of Deposit Money Banks, Banking Sector Deposits, Manufacturing Output, Monetary Policy Rate, and Exchange Rate were obtained from CBN Annual Report and Statement of Account, CBN Annual Statistics Bulletin, and National Bureau of Statistics Annual Abstract of Statistics, all of which are publicly available. Annual time series data over a 30-year period from 1980 to 2009 is used in the study.

All computations were performed using the ordinary least squares regression technique and the Stata version 9.2 integrated data analysis and statistical package.

\section{Econometric Analyses and Results}

\subsection{Estimation Results}

All data within our 30-year scope period were checked, one variable at a time. It was noted that the values of CV [ $\ln$ $\left.\left(\mathrm{Y} / \mathrm{Y}^{\mathrm{T}}\right)\right]_{\mathrm{t}}$ for 1981 and 1988 were aberrant as the two values were far from all other values for $\mathrm{CV}\left[\ln \left(\mathrm{Y} / \mathrm{Y}^{\mathrm{T}}\right)\right]_{\mathrm{t}}$. It is not clear why values for these two year deviates from other values, the observation may however have resulted from the fall in the value added in manufacturing outputs and the impact of overvalued exchange rates on international trade during the period.

The value for 1981 was 1242 while that of 1988 was 243 . However, removing the two values from our dataset would cause a significant reduction of our data size by two valuable degrees of freedom. Therefore, the best worst scenario is taken by treating the 1981 value as an outlier and removing it from the data set as it is significantly dispersed from average values for $\mathrm{CV}\left[\ln \left(\mathrm{Y} / \mathrm{Y}^{\mathrm{T}}\right)\right]_{\mathrm{t}}$. Our analyses are thus performed using a sample of $29 \mathrm{CV}[\mathrm{ln}$ $\left.\left(\mathrm{Y} / \mathrm{Y}^{\mathrm{T}}\right)\right]_{\mathrm{t}}$ values, as using the whole 30 values will provide spurious statistical results.

Table 3 describes how well our model fits the set of observations. Altogether, the model explains over 67 percent of the variation in Banking Sector liquidity over the 30-year estimation period. The adjusted R-squared (58 percent) and root MSE (0.10) indicates "a good" fit of the model for the provided data. Results of both the Breusch-Godfrey serial correlation Lagrange multiplier test and Durbin-Watson alternative test of autocorrelation in Table 2 confirms the assumption of no serial dependence within the time series data as null hypotheses are not rejected because $\mathrm{p}>0.05$.

\subsection{Determinants of Banking Sector Liquidity}

Table 1 presents a summary of the long-run determinants of Banking Sector liquidity, including the sum of the coefficients, their associated standard errors and tests of unit root for each estimated coefficient within the model.

Signs displayed by the coefficients are generally consistent with a prior expectations. For example, a fall in liquidity ratio or monetary policy rate should lead to a rise in the loan-to-deposit ratio. The relationship between 
loan-to-deposit ratio and changes in output is ambiguous. In answer to the question "Do bank loans have effects on output", Driscoll (2003:1) states that "answering the related question involves similar difficulties. Since the demand for loans presumably depends on the level of output, there is simultaneous equations bias in running a regression of output on the quantity of loans. There is also a reverse causality problem". He found that banking loans have small, often negative and insignificant effects on output.

Regression results from Table 1 indicate that only three regressors are significant for predicting Banking Sector liquidity. Specifically, loan-to-deposit ratio lagged one year, liquidity ratio, and the monetary policy rate as $\mathrm{p}=0.002<0.05$ in each case.

\subsection{Impact of Banking Crisis on Banking Sector Liquidity}

The estimated coefficients in Model 1 are used to provide forecasts of Nigerian Banking Sector liquidity during the period 2007 to 2009 . The 2007 forecast is obtained by using the actual loan-to-deposit ratio in 2006 and the actual values of other explanatory variables for 2007 to obtain the forecast loan-to-deposit forecasts for 2007 as follows.

(i). Take the actual value of $\ln (\mathrm{LD})$ for 2006 and the actual values of the other explanatory variables in 2007.

(ii). Forecast values for 2008 is subsequently obtained by feeding the forecasted value of $\ln$ (LD) for 2007 (as derived from (i) above) and the actual values of the other regressors in 2008.

(iii). The same steps are repeated to obtain forecast values of $\ln$ (LD) for 2009

Specifically, the dynamic forecasts are obtained as the expected value of the model:

$\mathbf{E}\left[\ln (L D)_{\mathrm{t}}\right]=\hat{\mathbf{a}}_{1} \ln (\mathbf{L D})_{\mathrm{t}-1}+\hat{\mathbf{a}}_{2} \ln (L Q)_{\mathrm{t}}+\hat{\mathbf{a}}_{3} \mathbf{C V}[\ln (\mathbf{C} / \mathbf{D})]_{\mathrm{t}}+\hat{\mathbf{a}}_{4} \mathbf{C V}\left[\ln \left(\mathrm{Y} / \mathbf{Y}^{\mathrm{T}}\right)\right]_{\mathrm{t}}+\hat{\mathbf{a}}_{5}\left[\ln \left(\mathbf{Y} / \mathbf{Y}^{\mathrm{T}}\right)\right]_{\mathrm{t}}+\hat{\mathbf{a}}_{6} \mathbf{r}+\varepsilon$

Where $a^{{ }^{\wedge},}$ is the estimated values of the explanatory variables.

The gap between actual loan-to-deposit ratios and forecasted loan-to-deposit values are then assessed to determine whether changes in Banking Sector liquidity during the financial crisis period 2007 to 2009 are above or below the general long term trend. According to Moore (2009:14) "If the actual loan-to-deposit ratio is above the predicted value this would suggest that commercial banks are less liquid than is consistent with fundamentals, while if the actual ratio is below the predicted value commercial banks are more liquid than what is consistent with economic fundamentals."

As shown in Figure 1, the actual loan-to-deposit ratio prior to the start of the financial crises in 2007 was below the predicted loan-to-deposit ratio. This is consistent with the fact that Nigerian deposit money banks during that period were significantly well capitalized due to the mandatory re-capitalization of Nigerian deposit money banks that was completed in December 2005. However, this position was reversed as the financial crises, which began late in 2007, worsened in 2008 with the predicted loan-to-deposit ratio becoming significantly lower than the actual loan-to-deposit ratio. The implication was that excess liquidity within the Nigerian Banking Sector was quickly eroded as deposit money banks wrote off unpaid loans and also had to meet unanticipated large cash withdrawals. Through a combination of measures including quantitative easing to bridge the liquidity gap and redemption of promissory notes issued by the monetary authorities etc, to the banking sector, the financial crisis began to abate in 2009 , evidenced by a narrowing in the gap between predicted and actual loan-to-deposit ratios.

\section{Summary and Conclusion}

This paper sought to trace the development and impact of Nigerian banking liquidity regulations; identify key determinants of Banking Sector liquidity in Nigeria; and assess the extent to which financial crisis affects Banking Sector liquidity regulations at deposit money banks. A liquidity demand model was specified, taking into account lagged ratio of total loan to total Banking Sector deposits; ratio of total specified liquid assets to total current liabilities; volatility of the ratio of currency in circulation to total Banking Sector deposits; and volatility of output to trend output. The estimated model was subsequently applied to explanatory variables of the financial crisis period between 2007 and 2009 to generate loan-to-deposit ratio projections with a view to determining whether actual Banking Sector liquidity during the financial crisis period was consistent with predicted Banking Sector liquidity.

The results suggest that during non-financial crisis periods, deposit money banks either hold excess liquidity or hold liquidity consistent with policy benchmarks. However, during financial crises periods, deposit money banks are significantly illiquidity relative to benchmarks, therefore, significantly increasing their vulnerability to distress.

The outcome of this paper is important for several reasons. First, getting liquidity monetary policies right is crucial in ensuring the survival of deposit money banks. Secondly, lagged loan-to-deposit ratio, liquidity ratio, and the monetary policy rate are key monetary policy instruments for determining the extent of Nigerian Banking Sector liquidity. Thus, in order to improve Banking Sector liquidity for example, the monetary authorities would have to reduce monetary policy rates and liquidity ratios. Changes made to prior year loan-to-deposit ratios also have a 
direct and positive impact on current loan-to-deposit ratios as both variables move in the same direction.

This study leaves open the possibility of future extensions. First, the study has relied exclusively on annual data; use of higher frequency data would however improve the accuracy of results in terms of the specific timing between actual and benchmark Banking Sector liquidity gaps. Secondly, it would be interesting to determine the significance of variables such as changes in general price level, parallel market spreads and volatility in crude oil prices on Banking Sector liquidity. Finally, cross country studies which compare the relationship between Banking Sector liquidity and Banking Sector monetary policy regulations in Nigeria with that of other developing countries such as Ghana, Kenya and Zambia would provide an insight into how outcomes differ amongst similar economies.

\section{References}

Adekanye, F. (1986). The Elements of Banking in Nigeria. (3rd ed.) F \& A Publishers Ltd.

Agénor, P-R., Aizenman, J., and Hoffmaister, A.W. (2004). The Credit Crunch in East Asia: What Can Bank Excess Liquid Assets Tell Us? Journal of International Money and Finance 23, pp. 27-49. doi:10.1016/j.jimonfin.2003.08.008, http://dx.doi.org/10.1016/j.jimonfin.2003.08.008

Ajayi, S.I., and Ojo, O. (1981). Money and Banking Analysis and Policy in the Nigerian Context London: George Allen and Unwin.

Alford, D. (2010). Nigerian Banking Reform: Recent Actions and Future Prospects. [Online] Available from: http://ssrn.com/abstract=1592599 (March 1, 2011).

Aspachs, O., Nier, E., Tiesset, M., (2005). Liquidity, Banking Regulation and the Macroeconomy: Evidence on Bank Liquidity Holdings from a Panel of UK-Resident Banks. Bank of International Settlements. [Online] Available from: http://www.bis.org/bcbs/events/rtf05AspachsNierTiesset.pdf (March 1, 2011).

Bordo, M., Eichengreen, B., Klingebiel, D., and Martinez-Peri, M. (2001). Is the Crisis Problem Growing More Severe? Economic Policy, April 2001, Volume 16, Number 32, pp. 51-82. doi:10.1111/1468-0327.00070, http://dx.doi.org/10.1111/1468-0327.00070

Brighi, P. (2002). Interbank Exchanges, Liquidity Management and Banking Crises. Economic Notes, Vol. 31, pp. 493-521. doi:10.1111/1468-0300.00095, http://dx.doi.org/10.1111/1468-0300.00095

Diamond, D. and Dybvig, D. (1983). Bank runs, deposit insurance and liquidity. The Journal of Political Economy, Vol. 91, No. 3. (Jun., 1983), pp. 401-419. doi:10.1086/261155, http://dx.doi.org/10.1086/261155

Driscoll, John C. (2003). Does Bank Lending Affect Output? Evidence from the U.S. States. FEDS Working Paper No. 2003-31. [Online] Available from: SSRN: http://ssrn.com/abstract=436584 (March 1, 2011).

Fadare, S. (2010). Recent Banking Sector Reforms and Economic Growth in Nigeria. Middle Eastern Finance and Economics ISSN: 1450-2889 Issue 8 pp $146-160$.

Fadare, S. (2011). Banking Crisis and Financial Stability in Nigeria. International Research Journal of Finance and Economics ISSN 1450-2887 Issue 63 pp 199 - 215.

Ibeabuchi, S.N. (2007). Overview of Monetary Policy in Nigeria. Economic and Financial Review Volume 45 December 2007 Number 44 pgs 15 - 37.

Moore, Winston. (2009). How do financial crises affect commercial bank liquidity? Evidence from Latin America and the Caribbean. MPRA Paper 21473, University Library of Munich. [Online] Available from: SSRN: http://mpra.ub.uni-muenchen.de/21473/1/MPRA_paper_21473.pdf (March 1, 2011).

NCEMA (2003). Structural Adjustment Programme in Nigeria: Causes, Processes and Outcomes. Global Development Network Delhi, India. [Online] Available from: http://depot.gdnet.org/cms/grp/general/Nigeria_proposal.pdf (March 1, 2011).

Nwankwo G. O. (1980). The Nigerian Financial System. London, Macmillan Publisher Ltd.

Okonjo-Iweala, N. and Osafo-Kwaako, P. (2007). Nigeria's economic reforms: progress and challenges. Brooklyn Global Economy and Development. [Online] Available from: http://www.brookings.edu/ /media/files/rc/papers/2007/0323globaleconomics_okonjo\%20iweala/20070323okonjo_ iweala.pdf (March 1, 2011).

Soludo, C.C. (2004). Consolidating the Nigerian banking industry to meet the development challenges of the 21st century. Address by Mr. Charles Chukwuma Soludo, Governor of the Central Bank of Nigeria, at the Special Meeting of the Bankers' Committee, Abuja, 6 July 2004. [Online] Available from: http://www.bis.org/review/r040727g.pdf (March 1, 2011). 
Soludo, C.C. (2009). Global Financial and Economic Crisis: How Vulnerable is Nigeria? Presentation by Professor Charles Chukwuma Soludo, Governor of the Central Bank of Nigeria, to the House of Representatives Committee on Banking and Currency on January 21, 2009. [Online] Available from: http://www.cenbank.org/out/speeches/2009/govadd-21-1-09.pdf . (March 1, 2011).

Saxegaard, Magnus (2006). Excess Liquidity and Effectiveness of Monetary Policy: Evidence from Sub-Saharan Africa. International Monetary Fund Working Paper /06/115 African Department May 2006. [Online] Available from: http://www.imf.org/external/pubs/ft/wp/2006/wp06115.pdf (March 1, 2011).

Uremadu, S.O. (2009). Determinants of Financial System Liquidity (1980 - 2005): Evidence from Nigeria. Annals of University of Bucharest, Economic and Administrative Series Nr. 3 pp. 123-137. [Online] Available from: http://annalseas.faa.ro/download/7\%20S.O.\%20Uremadu.pdf (March 1, 2011).

\section{Notes}

Note 1. According to the Central Bank of Nigeria, the Cowry has, for centuries, served Nigerians as an important form of currency. In 1860 the following system was in use: 40 Cowries formed a "String"; 50 Strings made a "head" and 10 heads comprised a "bag". In 1865, one bag of 20,000 shells was exchanged for one or two English Pounds.

Note 2. Several indigenous banks were established between 1929 and 1933 but only one (National Bank of Nigeria), survived well into Nigeria's independence from Britian.

Note 3. See page 11 of Martin Brownbridge's working paper "The Impact of Public Policy on the Banking System in Nigeria". Institute of Development Studies Working Paper No. 311996 for more details.

Note 4. Central Bank of Nigeria Monetary Policy Committee Meeting Communiqué (various issues).

Table 1. Determinants of Bank Sector Liquidity in Nigeria

\begin{tabular}{|c|c|c|c|}
\hline & Coefficients & $\mathbf{P}>|\mathbf{t}|$ & $\mathbf{t}$ \\
\hline Constant & $\begin{array}{l}-0.1638477 \\
(0.1169749)\end{array}$ & 0.175 & -1.4 \\
\hline $\ln (\mathrm{LD})_{\mathrm{t}-1}$ & $\begin{array}{c}0.3590232 \\
(0.1415306)\end{array}$ & 0.019 & 2.54 \\
\hline $\ln (L Q)_{t}$ & $\begin{array}{l}-0.2676051 \\
(0.1067374)\end{array}$ & 0.02 & -2.51 \\
\hline $\mathrm{CV}[\ln (\mathrm{C} / \mathrm{D})]_{\mathrm{t}}$ & $\begin{array}{l}0.2068227 \\
(0.446042)\end{array}$ & 0.647 & 0.46 \\
\hline $\mathrm{CV}\left[\ln \left(\mathrm{Y} / \mathrm{Y}^{\mathrm{T}}\right)\right]_{\mathrm{t}}$ & $\begin{array}{c}-0.000324 \\
(0.0004329)\end{array}$ & 0.462 & -0.75 \\
\hline$\left[\ln \left(\mathrm{Y} / \mathrm{Y}^{\mathrm{T}}\right)\right]_{\mathrm{t}}$ & $\begin{array}{c}-0.2036283 \\
(0.1642586)\end{array}$ & 0.228 & -1.24 \\
\hline Rate & $\begin{array}{c}-1.893157 \\
(0.5438543) \\
\end{array}$ & 0.002 & -3.48 \\
\hline
\end{tabular}

The estimates above represent the coefficients and corresponding standard errors of each explanatory variable 
Table 2. Tests of Autocorrelation

\begin{tabular}{|c|c|c|c|}
\hline \multicolumn{4}{|c|}{$\begin{array}{l}\text { Durbin-Watson d-statistic }(7,29)=1.442789 \\
\text { Durbin's alternative test for autocorrelation }\end{array}$} \\
\hline lags $(\mathrm{p})$ & chi2 & df & Prob $>$ chi 2 \\
\hline 1 & 1.536 & 1 & 0.2152 \\
\hline \multicolumn{4}{|c|}{ H0: no serial correlation } \\
\hline \multicolumn{4}{|c|}{ Breusch Godfrey LM test for autocorrelation } \\
\hline lags $(\mathrm{p})$ & chi2 & df & Prob $>$ chi2 \\
\hline 1 & 1.977 & 1 & 0.1597 \\
\hline
\end{tabular}

Table 3. Goodness of Fit

\begin{tabular}{|ll|}
\hline Observations & 29 \\
$\mathrm{~F}(6,22)$ & 7.46 \\
Prob $>$ F & 0.0002 \\
R-squared & 0.6706 \\
Adj R-squared & 0.5808 \\
Root MSE & 0.10634 \\
\hline
\end{tabular}

Table 4. Predictions

\begin{tabular}{|c|c|c|c|c|c|}
\hline Period & (Natural Log & Loan-to-Deposit Ratio & (Actual) & (Natural Log) Loan-to-Deposit Ratio & (Predicted) \\
\hline 2006 & & & -0.453 & & \\
\hline 2007 & & & -0.346 & & -0.314 \\
\hline 2008 & & & -0.212 & & -0.299 \\
\hline 2009 & & & -0.155 & & -0.146 \\
\hline
\end{tabular}

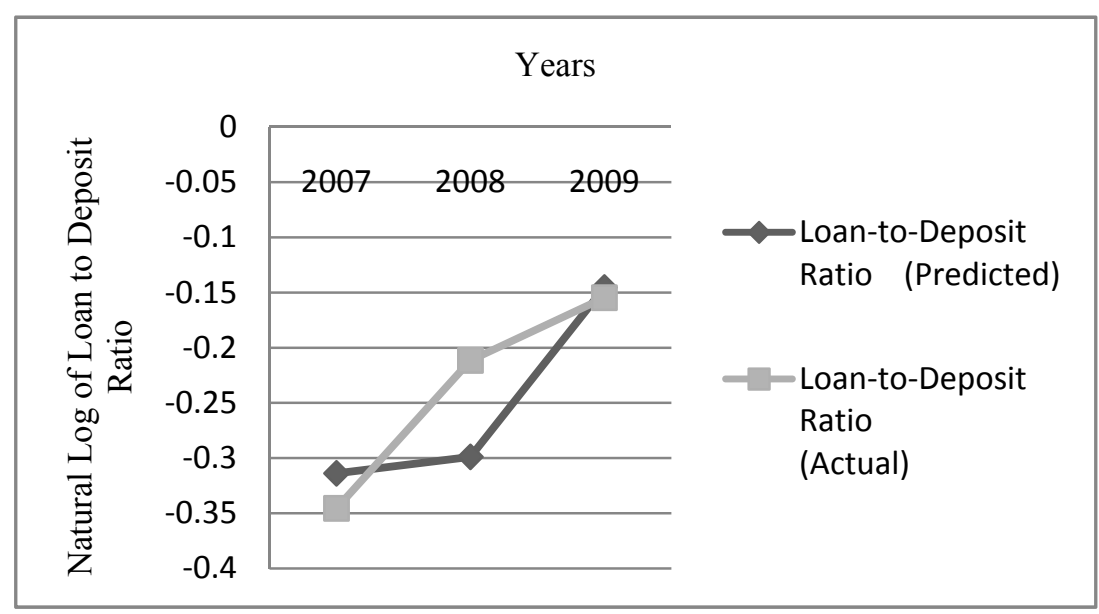

Figure 1. Predicted and Actual Loan to Depost Ratio 